\title{
EVALUATION OF THE RADIOPACITY OF ROOT CANAL SEALERS BY DIGITIZATION OF RADIOGRAPHIC IMAGES
}

\author{
AVALIAÇÃO DA RADIOPACIDADE DE CIMENTOS ENDODÔNTICOS \\ POR MEIO DA DIGITALIZAÇÃO DE IMAGENS RADIOGRÁFICAS
}

Juliane Maria Guerreiro TANOMARU1 ${ }^{1}$ Luciana CEZARE ${ }^{2}$, Marcelo GONÇALVES ${ }^{3}$, Mário TANOMARU FILHO ${ }^{4}$

\begin{abstract}
1- PhD, Graduate Student in Endodontics, Araraquara Dental School, State University of São Paulo, UNESP, Araraquara, SP, Brazil.
2- DDS, Graduate Student in Dentistry, Araraquara Dental School, State University of São Paulo, UNESP, Araraquara, SP, Brazil.

3- Assistant Professor of Radiology, Araraquara Dental School, State University of São Paulo, UNESP, Araraquara, SP, Brazil.

4- Associate Professor, Department of Endodontics, Araraquara Dental School, State University of São Paulo, UNESP, Araraquara, SP, Brazil.

Corresponding address: Prof. Dr. Mário Tanomaru Filho - Rua Humaitá, 1680, Caixa Postal 331, Centro, Cep.: 14801-903 - Araraquara, SP, Brasil - Phone +55-16-3301-6390, Fax.+55-16-3301-6392. Email: tanomaru@uol.com.br

Received:June 06, 2004 - Returned for modification: August 17, 2004 - Accepted: October 06, 2004
\end{abstract}

\begin{abstract}
$T_{\text {he }}$ based (Sealapex), two resin-based (Sealer 26 and AH Plus), and a silicone-based root canal sealer (Roeko Seal). Specimens, measuring $10 \mathrm{~mm}$ in diameter and $1 \mathrm{~mm}$ in thickness, were radiographed simultaneously with an aluminum step wedge using occlusal films, according to ISO 6876/2001 standards. Radiographs were digitized, and the radiopacity of sealers was compared to the different thicknesses of the aluminum step wedge, using the VIXWIN 2000 software. Results demonstrated that AH Plus was the most radiopaque sealer, while Sealapex was the least radiopaque $(\mathrm{p}<0.05)$. Roeko Seal, Endofill and Sealer 26 presented intermediate radiopacity values. Sealapex presented less radiopacity than the other types of root canal sealers.

Uniterms: Root canal filling materials; Radiopacity.
\end{abstract}

\section{RESUMO}

$O$

objetivo deste trabalho foi avaliar a radiopacidade de cimentos endodônticos à base de óxido de zinco e eugenol (Endofill), hidróxido de cálcio (Sealapex), resina (Sealer 26 e AH Plus) e silicone (Roeko Seal). Os corpos de prova foram padronizados com 10 milímetros de diâmetro e 1 milímetro de espessura e radiografados conjuntamente com uma escala de alumínio empregando-se filmes oclusais, de acordo com as Normas ISO 6876/2001. As radiografias foram digitalizadas e as radiopacidades dos cimentos comparadas à escala de alumínio com diferentes espessuras, utilizando o software VIXWIN 2000. Os resultados demonstraram que o AH Plus foi o cimento mais radiopaco e o Sealapex apresentou menor radiopacidade $(\mathrm{p}<0,05)$, sendo intermediários os resultados para os cimentos Roeko Seal, Endofill e Sealer 26. Sealapex apresenta menor radiopacidade que outros tipos de cimentos endodônticos.

Unitermos: Material obturador de canal radicular; Radiopacidade.

\section{INTRODUCTION}

The ideal root canal sealer should present, among other physical/chemical properties, enough radiopacity to allow distinction from the adjacent anatomical structures ${ }^{2,11,14,10}$, such as bone and tooth ${ }^{13}$. Higginbotham ${ }^{7}$ (1967) was the first researcher to publish a study comparing the radiopacity of various endodontic sealers and gutta-percha cones used to fill root canals ${ }^{7}$. Eliasson and Haasken ${ }^{4}$ (1979) established a comparison standard for radiopacity studies, using optical radiographic density measurements for impression materials and an equivalent thickness of aluminum capable of producing similar radiographic density.

Beyer-Olsen and Orstavik² (1981) included in their studies a reproducible comparison standard using an aluminum step wedge with $2 \mathrm{~mm}$-increments to determine the radiopacity of several root canal sealers. Their results showed that most sealers investigated were more radiopaque than dentin. Tagger and Katz ${ }^{16}$ using similar methodology evaluated the radiopacity of root-end filling materials.

The aim of this study was to evaluate the radiopacity of five root canal sealers in comparison to the radiopacity of 
an aluminum step wedge, according to the ISO 6876/2001 standards ${ }^{9}$, which recommend that root canal filling materials should be at least as radiopaque as a 3 mm-thick aluminum wedge.

\section{MATERIALS AND METHODS}

Five root canal sealers were evaluated in this study: Endofill (Dentsply Ind. e Com. Ltda., Petrópolis, RJ, Brazil), Sealapex (Kerr Corp., Orange, CA, USA), Sealer 26 (Dentsply Ind. e Com. Ltda., Petrópolis, RJ, Brazil), RSA Roeko Seal (Roeko, Langenau, Germany), and AH Plus (Dentsply De Trey Gmbh, Konstanz, Germany). The materials were prepared according to manufacturers' instructions. Five specimens, measuring $10 \mathrm{~mm}$ in diameter and $1 \mathrm{~mm}$ in thickness, were fabricated from each material tested. Metallic matrices were made and impressions were taken using a light-bodied silicone-based impression material. Samples of the prepared sealers were then inserted into the impressions and stored in a moist chamber (incubator) at $37^{\circ} \mathrm{C}$, until completely set.

Following that, the specimens were placed onto five occlusal radiographic films (Insight - Kodak Comp, Rochester, NY, USA) and exposed, along with an aluminum step wedge with thickness varying from 2 to $16 \mathrm{~mm}$ in $2 \mathrm{~mm}$ increments (Figure 1). A GE-1000 X-ray machine (General Electric, Milwaukee, WI, USA) operating at $50 \mathrm{Kv}, 10 \mathrm{~mA}, 18$ pulses/s, and focus-film distance of $33.5 \mathrm{~cm}$, was used. Radiographs were digitized using a desktop scanner (SnapScan 1236 - Agfa, Deutschland), and the digitized images were imported into the VIXWIN 2000 software (Gendex, Desplaines, IL, USA), where a tool was applied to identify equal-density areas in the radiographic images (equal-density tool). This procedure allowed comparison between the densities of different sealers and the radiopacity of different degrees of thickness of the aluminum step wedge. Using the computer mouse, an area corresponding to the specimen was selected from each radiographic image, in order to verify which thickness of the aluminum step wedge was detected by the software as being equivalent to the radiographic density of the sample. This determined the

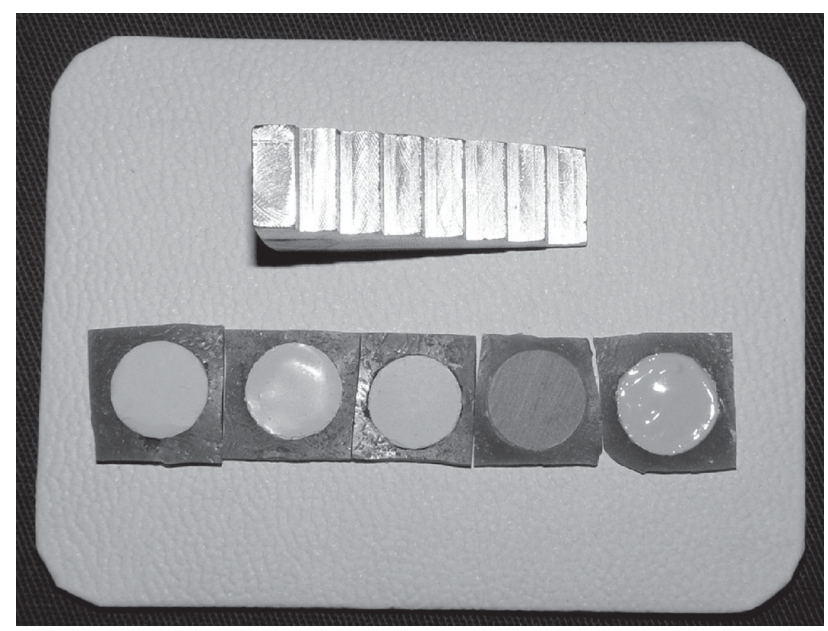

FIGURE 1- Occlusal film, specimens, and aluminum step wedge equivalence of radiopacity of the selected material compared to a particular thickness of aluminum, measured in millimeters. Results were analyzed by calculating the means of five measurements for each sample. Data were submitted to statistical analysis using ANOVA and Tukey test.

\section{RESULTS}

Results showed that the AH Plus sealer presented the greatest radiopacity $(\mathrm{p}<0.05)$ and was equivalent to $16 \mathrm{~mm}$ of aluminum (Figure 2). Roeko Seal and Endofill sealers presented radiopacity equivalent to $6 \mathrm{~mm}$ of aluminum (Figure 3). The calcium hydroxide-based sealers were the least radiopaque $(\mathrm{p}<0.05)$ : Sealer 26 was equivalent to $4 \mathrm{~mm}$ of aluminum, while Sealapex was equivalent to $2 \mathrm{~mm}$ of aluminum (Figure 4).

\section{DISCUSSION}

In 1990, Katz, et al. ${ }^{11}$ (1990) evaluated the radiopacity of gutta-percha points used in endodontic treatment, verifying

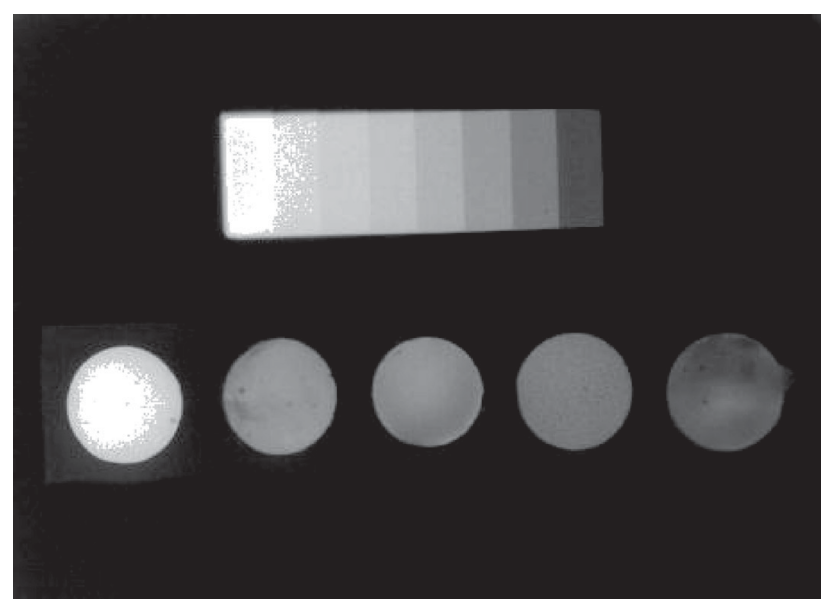

FIGURE 2- Radiograph showing the radiopacity of AH Plus sealer and its equivalence to the aluminum step wedge

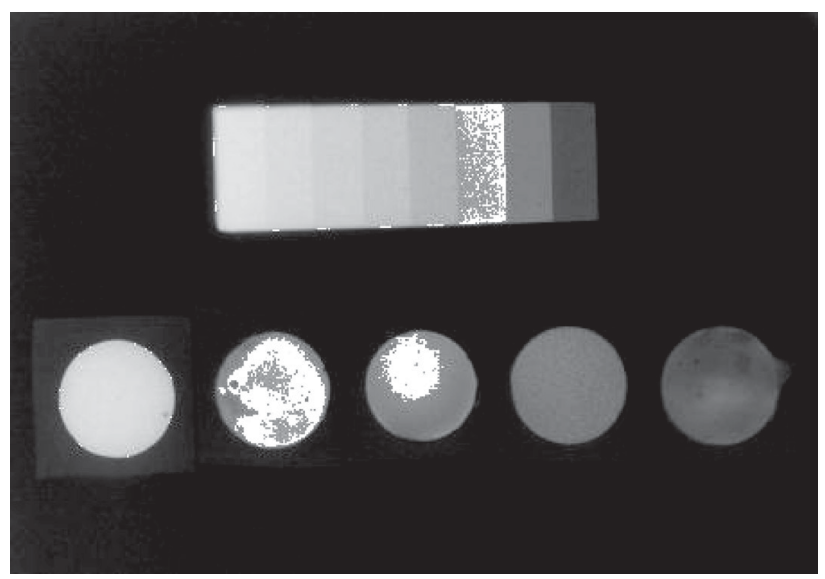

FIGURE 3- Radiograph showing the radiopacity of Endofill and Roeko Seal and their equivalence to the aluminum step wedge 
that the average radiopacity of the points was approximately the same as 7.4mm of aluminum. McComb \& Smith ${ }^{14}$ (1976) evaluated, among other physical properties, the radiopacity of nine brands of root canal sealers in comparison to two polycarboxylate-based experimental endodontic materials. The authors concluded that reduction in the amount of radiopaque substances in the sealers led to decrease in radiopacity.

Several other studies have evaluated the radiopacity of composite resin materials using an aluminum step wedge as comparison standard ${ }^{3,5,6}$.

The radiopacity of root-end filling materials was evaluated by Shah, et al. ${ }^{15}$ (1996) and Laghios, et al. ${ }^{13}$ (2000). These authors reported that most of these materials presented radiopacity equivalent to at least 2 millimeters of aluminum, with the exception of glass ionomer-based materials, which did not meet the minimum requirements for use as root-end filling material.

The ISO 6876/2001 ${ }^{9}$ establishes that root canal sealers should be at least as radiopaque as $3 \mathrm{~mm}$ of aluminum thickness ${ }^{11}$. According to the ANSI/ADA ${ }^{1}$ specification \#57, endodontic filling materials should present a difference in radiopacity equivalent to at least $2 \mathrm{~mm}$ of aluminum in comparison to bone or dentin ${ }^{1}$. Therefore, all sealers evaluated presented the minimum radiopacity required by these standards, except for Sealapex.

AH Plus sealer contains zirconium oxide, which contributes for its greater radiopacity in relation to the other materials tested. On the other hand, Roeko Seal, a polydimethylsiloxane-based material, presented radiopacity similar to the zinc oxide and eugenol-based sealer (Endofill). The calcium hydroxide-based materials, Sealer 26 and Sealapex, showed lower radiopacity.

Sealapex presented radiopacity values slightly below those defined by the ISO ${ }^{9}$. Kuga, et al. ${ }^{12}$ (1988) suggested the addition of iodoform to Sealapex, with the purpose of increasing the radiopacity of this material. This addition did not affect the sealing properties ${ }^{9}$ or biocompatibility of materials (Holland, et al. ${ }^{8}, 1990$ ).

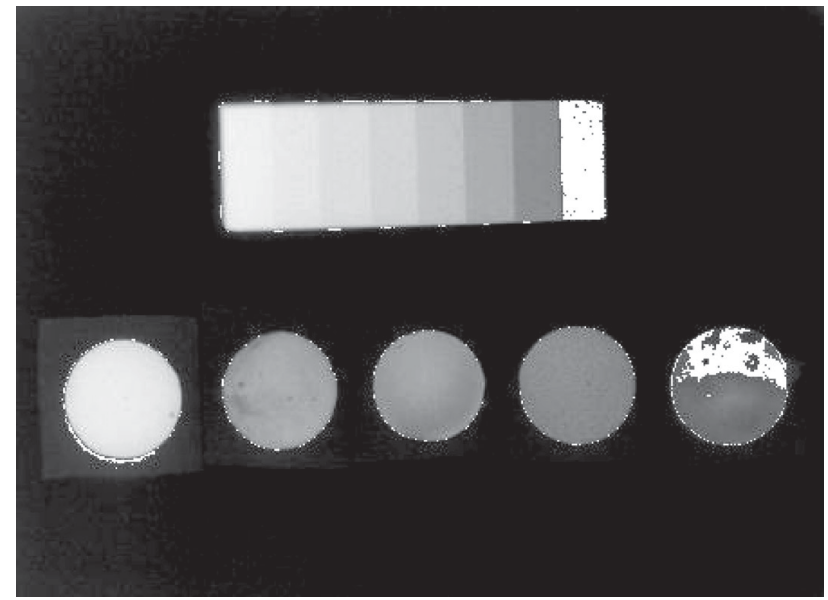

FIGURE 4- Radiograph showing the radiopacity of Sealapex and its equivalence to the aluminum step wedge

\section{CONCLUSION}

Analysis of the present results led to the conclusion that, although the materials tested presented different radiopacities, AH Plus, Endofill, Roeko Seal and Sealer 26 presented radiopacity values above the minimum values proposed by the ISO, except for Sealapex, which presented radiopacity values slightly below those specified by the ISO norms.

\section{REFERENCES}

1- American Dental Association. Specification \# 57 for endodontic filling materials. J Am Dent Assoc 1984;108:88.

2- Beyer-Olsen EM, Orstavik D. Radiopacity of root canal sealers. Oral Surg Oral Med Oral Pathol 1981;51:320-8.

3- Curtis Jr. PM, von Fraunhofer JA, Farman AG. The radiographic density of composite restorative resins. Oral Surg Oral Med Oral Pathol 1990;70:226-30.

4- Eliasson ST, Haasken B. Radiopacity of impression materials. Oral Surg Oral Med Oral Pathol 1979;47:485-91.

5- Gürdal P, Akdeniz BG. Comparison of two methods for radiometric evaluation of resin-based restorative materials. Dentomaxillofac Radiol 1998; 27:236-9.

6- Hara AT, Serra MC, Rodrigues Jr. AL. Radiopacity of glass-ionomer/ composite resin hybrid materials. Braz Dent J 2001;12:85-9.

7- Higginbotham TL. A comparative study of physical properties of five commonly used root canal sealers. Oral Surg Oral Med Oral Pathol 1967;24:89-101.

8- Holland R, Mello W, Souza V, Nery MJ, Bernabé, PFE, Otoboni Filho JA. Comportamento dos tecidos periapicais de dentes de cães após obturação de canal com Sealapex acrescido ou não de iodofórmio. Rev Odontol UNESP 1990;19:97-104.

9- International Organization for Standardization ISO 6876 -2001: Dental root sealing materials.

10- Imai Y, komabayashi T. Properties of a new injectable type of root canal filling resin and adhesiveness to dentin. J Endod 2003;29:20-3.

11- Katz A, Kaffe I, Littner M, Tagger M, Tamse A. Densitometric measurement of radiopacity of gutta-percha cones and root dentin. J Endod 1990;16:211-3.

12- Kuga MC, Moraes IG, Berbert A. Capacidade seladora do cimento Sealapex puro ou acrescido de iodofórmio. Rev Odontol USP; 1988;2:139-42.

13- Laghios CD, Benson BW, Gutmann JL, Cutler CW. Comparative radiopacity of tetracalcium phosphate and other root-end filling materials. Int Endod J 2000;33:311-5.

14- McComb D, Smith DC. Comparison of physical properties of polycarboxylate-based and conventional root canal sealers. J Endod 1976;2:228-35.

15- Shah PMM, Chong BS, Sidhu SK, Ford TRP. Radiopacity of potential root-end filling materials. Oral Surg Oral Med Oral Pathol 1996;81:4769 .

16- Tagger M, Katz A. A standard for radiopacity of root-end (retrograde) filling materials is urgently needed. I Endod J 2004;37:260-4. 